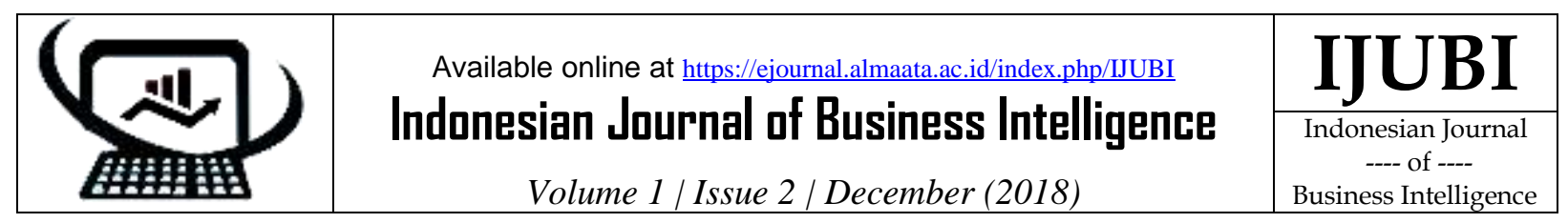

\title{
ANALISIS KEPUASAN MAHASISWA TERHADAP \\ KINERJA PORTAL UNIVERSITAS ALMA ATA MENGGUNAKAN PENDEKATAN END-USER COMPUTING SATISFACTION DAN DELONE AND MCLANE MODEL
}

Asti Ratnasari

Program Studi Sistem Informasi, Fakultas Komputer, Universitas Alma Ata astiratnasari0103@gmail.com

Jl. Brawijaya No. 99 Yogayakarta

\begin{abstract}
Keywords:
Informastion

System, User

Satisfaction, EUCS,

Delone and McLean

Model.
\end{abstract}

\section{Kata Kunci:}

Sistem Informasi, Kepuasan Pengguna, EUCS, Delone and McLean Model.

\begin{abstract}
User satisfaction is one aspect of evaluating information systems. The information system is said well if the users satisfied with the information system applied in the organization. End User Computing Satisfaction and Delone and McLean Model of Information Systems, both of them are information system models to determine user satisfaction. This study aims to determine the factors that influence users on the performance of Portal UAA (content, accuracy, format, ease of use, timeliness, information quality, system quality, and service quality). Furthermore, this study also modeled new user satisfaction with it customization of the End User Satisfaction Information System and Delone and McLean Information Systems. Analysis of the data used for processing data is multiple regression analysis. Multiple regression analysis to find the influence between independent variables and dependent variable.
\end{abstract}

Abstrak
Kepuasan pengguna merupakan salah satu aspek untuk mengevaluasi sistem informasi. Sistem informasi dikatakan baik, jika pengguna merasa puas terhadap sistem informasi yang diterapkan dalam suatu organisasi. End User Computing Satisfaction dan Delone and McLean Model of Information Systems, keduanya merupakan model evaluasi sistem informasi untuk mengetahui kepuasan pengguna. Penelitian ini bertujuan untuk mengetahui faktor-faktor yang mempengaruhi kepuasan pengguna terhadap kinerja Portal UAA (konten, akurasi, format, kemudahan penggunaan, ketepatan waktu, kualitas informasi, kualitas sistem dan kualitas layanan). Lebih lanjut, penelitian ini juga memodelkan kepuasan pengguna baru dengan memodifikasi End User Computing Satisfaction dan Delone and McLean Model of Information Systems. Analisis data yang digunakan untuk pengolahan data adalah analisis regresi berganda. Analisis regresi berganda digunakan untuk mengetahui pengaruh antar variabel independen terhadap variabel dependen.

\section{Pendahuluan}

Dunia pendidikan merupakan salah satu kunci sumber daya manusia di suatu negara. Pendidikan yang maju dan berkualitas dapat meningkatkan sumber daya manusia. Kemajuan teknologi informasi dan komunikasi mendorong semua sektor termasuk bidang pendidikan menghadapi persaingan yang sangat ketat di tingkat nasional dan global. Hal ini dilakukan agar suatu instansi memiliki keunggulan kompetitif dibandingkan yang lainnya. Saat ini sistem informasi telah menjadi tulang punggung hampir di semua organisasi [1].

Di perguruan tinggi, peningkatan pelayanan kepada civitas akademika dengan menghadirkan sistem akademik. Adanya sistem akademik ini diharapkan dapat menyelesaikan permasalahan 
yang ada di perguruan tinggi, karena semakin kompleksnya permasalahan yang muncul. Sistem informasi akademik dapat memperbaiki administrasi akademik yang sebelumnya dilakukan secara manual [2]. Sistem Informasi memiliki dampak yang luas terhadap strategi dan efektivitas organisasi. Penting bagi suatu organisasi mengidentifikasi apakah sistem informasi yang dipakai sudah memenuhi tujuan organisasi [3].

Portal Universitas Alma Ata (Portal UAA) adalah sistem informasi terpadu yang digunakan seluruh civitas akademika Universitas Alma Ata. Tujuan disediakannya Portal UAA agar mahasiswa, dosen dan karyawan dapat menggali informasi terbaru seputar akademik. Bagi mahasiswa, adanya Portal UAA ini agar kegiatan akademik berjalan dengan baik dan up-to-date. Melalui Portal UAA, mahasiswa mendapatkan informasi akademik, melakukan rencana studi, mengetahui jadwal untuk tiga hari ke depan, informasi pembayaran dan lain-lain, bahkan mahasiswa secara langsung dapat melakukan sapa rektor terkait ide kreatif atau keluhan pelayanan kepada Rektor Universitas Alma Ata.

Portal UAA diperkenalkan kepada mahasiswa mulai awal tahun 2017. Portal UAA diharapkan dapat memberikan informasi yang akurat, cepat dan tepat. Oleh karena itu, dibutuhkan evaluasi sistem informasi mengenai layanan dan kepuasan pengguna, baik dari sudut pandang organisasi untuk memperkirakan manfaat dan dari sudut pandang sistem informasi untuk memperbaiki kinerja. Banyak penulis setuju bahwa pengukuran kepuasan pengguna (user satisfaction) sangat berguna dan mudah untuk mengevaluasi kesuksesan sistem informasi [4]. Kepuasan pengguna didefinisikan sebagai respon penerima terhadap penggunaan output suatu sistem informasi [5]. Kepuasan pengguna umumnya dianggap sebagai salah satu ukuran terpenting keberhasilan sistem informasi [6]. Banyak model evaluasi sistem informasi untuk mengukur kepuasan pengguna, diantaranya end user computing satisfaction dan delone and mclean model of information systems.

End user computing satisfaction adalah model evaluasi sistem informasi yang dikembangkan oleh Doll dan Torkzadeh pada tahun 1988. Doll dan Torkzadeh mengembangkan dan memvalidasi instrumen end-user computing 67 "Asti Ratnasari" satisfaction yang terdiri dari lima komponen: konten, akurasi, format, kemudahan, dan ketepatan waktu. End-user computing satisfaction Penelitian Antoniou, G.; Papoglou (2015) menunjukkan bahwa pengguna akhir sistem Business Intelligence \& Analytics (BI\&A) memiliki sikap positif yang sangat kuat terhadap semua model-model end-user computing satisfaction [7]. Demikian pula pada penelitian Ilias, Razak, Rahman, \& Yasoa' (2009) hasil empiris penelitian memberikan dukungan untuk model End User Computing Satisfaction berkaitan dengan faktor-faktor yang berpengaruh terhadap kepuasan pengguna pada sistem akuntansi (konten, akurasi, format, kemudahan, dan ketepatan waktu) [8].

Delone and mclean model of information systems adalah model kesuksesan yang dikembangkan oleh William H. DeLone dan Ephraim R. McLean. Beberapa tahun terakhir, model DeLone dan McLean baik dalam versi aslinya maupun versi terbaru menjadi kerangka evaluasi yang banyak digunakan dalam penelitian sistem informasi. Penelitian Sirsat \& Sirsat (2016) menunjukkan bahwa model penelitian membantu memahami dampak UDISE terhadap keuntungan individu dan organisasi [5]. Hubungan hipotesis antara enam variabel secara signifikan mendukung sistem informasi. Lebih lanjut, penelitian Jaafreh (2017) menunjukkan bahwa sebagian besar variabel memberikan kontribusi yang cukup untuk predisi variabel dependen. IS Quality (system quality, information quality, service quality) memiliki pengaruh positif yang signifikan terhadap user satisfaction [9]. DeLone and McLean model dan variabel-variabelnya membuktikan bahwa model ini dapat digunakan sevagai alat yan digunakan bagi pengambil keputusan di bank dalam mengevaluasi pelaksanaan sistem informasi.

Berdasarkan penjabaran di atas penelitian ini akan menggunakan end user computing satisfaction dan delone and mclean model of information systems untuk mengkaji faktor-faktor yang mempengaruhi kepuasan pengguna terhadap Portal UAA. Selanjutnya, hasil penelitian ini diharapkan dapat digunakan sebagai rujukan Universitas Alma Ata untuk mengevaluasi kinerja Portal UAA dan menentukan langkahlangkah perbaikan dalam tahap pengembangan sistem selanjutnya. 


\section{Landasan Teori}

\section{Sistem Informasi}

Sistem informasi adalah sistem perangkat lunak untuk menangkap, mengirim, menyimpan, mengambil, memanipulasi, atau menampilkan informasi sehingga mendukung orang, oranisasi, atau sistem perangkat lunak lainnya [1]. Boell \& Cecez-Kecmanovic (2015) menyatakan bahwa sistem informasi melibatkan berbagai teknologi informasi seperti komputer, perangkat lunak, basis data, sistem komunikasi, Internet, perangkat seluler dan lain-lain, untuk melakukan tugastugas dalam berbagai organisasi atau konteks sosial. Sistem informasi diidentifikasi ke dalam empat konseptualisasi yang berbeda yaitu aspek teknologi, sosial, sosio-teknis dan proses. Keempat konseptualisasi ini didasarkan pada aspek utama yang ditekankan oleh masingmasing definisi: (a) aspek teknologi, termasuk pengolahan, penyimpanan dan transformasi data; (b) aspek sosial, yang menekankan bahwa sistem informasi adalah sistem sosial secara intrinsik; (c) aspek sosio-teknis, dengan alasan bahwa sistem informasi mencakup komponen sosial dan teknologi yang saing terkait; dan (d) aspek proses, mengkonsetualisasikan sistem informasi dalam hal melakukan dan mendukung kegiatan dan proses [10].

\section{End-User Computing Satisfaction}

End user computing satisfaction adalah model evaluasi sistem informasi yang dikembangkan oleh Doll dan Torkzadeh pada tahun 1988 [7]. Doll dan Torkzadeh mengembangkan dan memvalidasi instrumen end-user computing satisfaction yang terdiri dari lima komponen: konten, akurasi, format, kemudahan, dan ketepatan waktu [6]. Sekundera (2006) menyatakan bahwa instrumen end-user computing satisfaction dianggap komprehensif untuk mengukur kepuasan pengguna akhir karena instrumen dibuat dengan mengumpulkan itemitem kuesioner dari penelitian-penelitian sebelumnya dan merumuskan item-item mengenai kemudahan penggunaan (ease of use) karena sebelumnya diabaikan dalam pertanyaan mengenai kepuasan [11].

\section{DeLone and McLean Model of Informasion Systems Success}

Model DeLone dan McLean merupakan model kesuksesan sistem informasi yang pertama kali diperkenalkan pada tahun 1992. Model DeLone dan McLean mencoba untuk menjelaskan hubungan antar enam dimensi, yaitu: information quality, system quality, use, user satisfaction, individual impact, dan organizationa impact [12].

DeLone \& McLean memperbaharui modelnya untuk e-commerce. Kualitas layanan ditambahkan untuk merefleksikan "dukungan keseluruhan yang disampaikan oleh penyedia layanan". Kualitas layanan mengacu pada variabel seperti kegunaan, ketersediaan, keandalan, kemampuan beradaptasi, dan waktu respons (misal: waktu download)" untuk ecommerce [13].

\section{Metode}

Kerangka penelitian digunakan untuk menganalisis kepuasan mahasiswa terhadap Portal UAA. Kerangka Penelitian dibuat dengan memodifikasi end-user computing satisfaction dan DeLone and McLean Model.

Variabel yang dianalisis dalam penelitian ini dibedakan menjadi variabel dependen dan variabel independen. Variabel dependen dalam penelitian ini adalah variabel kepuasan pengguna, sedangkan variabel independennya adalah konten, akurasi, format, kemudahan penggunaan, ketepatan waktu, kualitas informasi, kualitas sistem, kualitas layanan dan kepuasan pengguna.

Kerangka penelitian dapat digambarkan untuk menganalisis kepuasan mahasiswa terhadap kinerja Portal UAA, seperti pada gambar 1 .

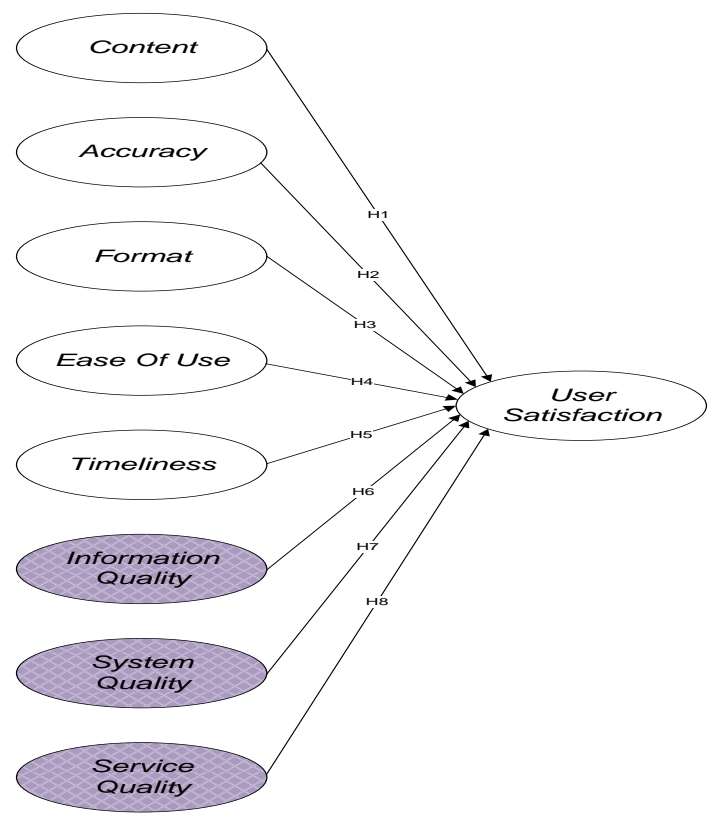

Gambar 1. Kerangka Penelitian 
Tabel 1. Definisi Konstruk

\begin{tabular}{|c|c|}
\hline Konstruk & Definisi \\
\hline Konten & $\begin{array}{l}\text { Sejauh mana konten sistem informasi } \\
\text { dianggap tepat dan memadai [7]. }\end{array}$ \\
\hline Akurasi & $\begin{array}{l}\text { Sejauh mana sistem informasi dianggap } \\
\text { akurat [7]. }\end{array}$ \\
\hline Format & $\begin{array}{l}\text { Sejauh mana keluaran sistem informasi } \\
\text { dianggap bermanfaat dan jelas [7]. }\end{array}$ \\
\hline $\begin{array}{l}\text { Kemudahan } \\
\text { Penggunaan }\end{array}$ & $\begin{array}{l}\text { Sejauh mana sistem informasi dianggap } \\
\text { mudah [7]. }\end{array}$ \\
\hline $\begin{array}{l}\text { Ketepatan } \\
\text { Waktu }\end{array}$ & $\begin{array}{l}\text { Sejauh mana sistem menyediakan } \\
\text { informasi terkini dan tepat waktu [7]. }\end{array}$ \\
\hline $\begin{array}{l}\text { Kualitas } \\
\text { informasi }\end{array}$ & $\begin{array}{l}\text { Karakteristik yang diinginkan dari } \\
\text { keluaran sistem; yaitu laporan } \\
\text { manajemen dan halaman web. } \\
\text { Misalnya: relevansi, kemampuan } \\
\text { memahami, akurasi, keringkasan, } \\
\text { kelengkapan, pemahaman, mata uang, } \\
\text { ketepatan waktu, dan kegunaan [3]. }\end{array}$ \\
\hline $\begin{array}{l}\text { Kualitas } \\
\text { Sistem }\end{array}$ & $\begin{array}{l}\text { Karakteristik yang diinginkan dari } \\
\text { sistem informasi. Misalnya: kemudahan } \\
\text { penggunaan, fleksibilitas sistem, } \\
\text { keandalan sistem, dan kemudahan } \\
\text { belajar, serta fitur sistem intuitif, } \\
\text { kecanggihan, fleksibilitas, dan waktu } \\
\text { respon [3]. }\end{array}$ \\
\hline $\begin{array}{l}\text { Kualitas } \\
\text { Layanan }\end{array}$ & $\begin{array}{l}\text { Kualitas dukungan yang diterima } \\
\text { pengguna sistem dari organisasi sistem } \\
\text { informasi dan personil pendukung } \\
\text { teknologi informasi. Misalnya: } \\
\text { responsif, akurasi, reliabilitas, } \\
\text { kompetensi teknis, dan empati staff } \\
\text { personalia teknologi informasi [3]. }\end{array}$ \\
\hline $\begin{array}{l}\text { Kepuasan } \\
\text { Pengguna }\end{array}$ & $\begin{array}{l}\text { Respon penerima terhadap penggunaan } \\
\text { output suatu sistem informasi [3]. }\end{array}$ \\
\hline
\end{tabular}

Hipotesis disusun berdasarkan kerangka penelitian yang telah dibuat sebelumnya. Terdapat delapan hipotesis yang dirumuskan dan akan diuji pada penelitian ini, yaitu:

H1: Konten akan memiliki pengaruh positif terhadap kepuasan pengguna pada kinerja Portal UAA.

H2: Akurasi akan memiliki pengaruh positif terhadap kepuasan pengguna pada kinerja Portal UAA.

H3: Format akan memiliki pengaruh positif terhadap kepuasan pengguna pada kinerja Portal UAA.
H4: Kemudahan Penggunaan akan memiliki pengaruh positif terhadap kepuasan pengguna pada kinerja Portal UAA.

H5: Ketepatan waktu akan memiliki pengaruh positif terhadap kepuasan pengguna pada kinerja Portal UAA.

H6: Kualitas informasi akan memiliki pengaruh positif terhadap kepuasan pengguna pada kinerja Portal UAA.

H7: Kualitas sistem akan memiliki pengaruh positif terhadap kepuasan pengguna pada kinerja Portal UAA.

H8: Kualitas layanan akan memiliki pengaruh positif terhadap kepuasan pengguna pada kinerja Portal UAA.

Penelitian ini bertujuan untuk menguji hipotesis yang telah dirumuskan sebelumnya, sehingga jenis penelitian yang akan digunakan adalah metode penelitian kuantitatif. Analisis data instrumen penelitian menggunakan analisis regresi berganda. Instrumen penelitian dibuat menggunakan skala likert lima (5) poin. Sampel penelitian menggunakan mahasiswa aktif S1 Universitas Alma Ata angakatan 2017 dari 14 program studi. Total sampel penelitian sebanyak 222 responden.

\section{Hasil dan Pembahasan}

Penelitian ini menggunakan instrumen penelitian untuk mengukur kepuasan mahasiswa terhadap Portal UAA. Uji coba instrumen penelitian diberikan kepada 30 mahasiwa. Uji validitas dan reliabilitas memperlihatkan koefisien korelasi item total bergerak antara 0,337 sampai 0,870 dan nilai cronbach's alpha 0,968. Hasil perhitungan menyatakan semua pernyataan valid karena di atas batas kritis yaitu 0,306. Hasil perhitungan uji validitas ditunjukkan pada Tabel 7. Secara keseluruhan item pertanyaan dinyatakan reliabel karena nilai cronbach's alpha di atas 0,6. Hasil perhitungan uji reliabilitas ditunjukkan pada Tabel 2. 
Tabel 2. Uji Validitas

\begin{tabular}{|c|c|c|}
\hline $\begin{array}{c}\text { Item } \\
\text { Pertanyaan }\end{array}$ & Nilai Koefisien $r$ & Simpulan \\
\hline Item 1 & 0,337 & Valid \\
\hline Item 2 & 0,719 & Valid \\
\hline Item 3 & 0,746 & Valid \\
\hline Item 4 & 0,870 & Valid \\
\hline Item 5 & 0,657 & Valid \\
\hline Item 6 & 0,690 & Valid \\
\hline Item 7 & 0,679 & Valid \\
\hline Item 8 & 0,760 & Valid \\
\hline Item 9 & 0,687 & Valid \\
\hline Item 10 & 0,599 & Valid \\
\hline Item 11 & 0,657 & Valid \\
\hline Item 12 & 0,695 & Valid \\
\hline Item 13 & 0,812 & Valid \\
\hline Item 14 & 0,665 & Valid \\
\hline Item 15 & 0,798 & Valid \\
\hline Item 16 & 0,792 & Valid \\
\hline Item 17 & 0,482 & Valid \\
\hline Item 18 & 0,768 & Valid \\
\hline Item 19 & 0,850 & Valid \\
\hline Item 20 & 0,749 & Valid \\
\hline Item 21 & 0,431 & Valid \\
\hline Item 22 & 0,568 & Valid \\
\hline Item 23 & 0,652 & Valid \\
\hline Item 24 & 0,713 & Valid \\
\hline Item 25 & 0,630 & Valid \\
\hline Item 26 & 0,770 & Valid \\
\hline Item 27 & 0,698 & Valid \\
\hline Item 28 & 0,756 & Valid \\
\hline Item 29 & 0,782 & Valid \\
\hline Item 30 & 0,780 & Valid \\
\hline Item 31 & 0,818 & Valid \\
\hline
\end{tabular}

Tabel 3. Uji Reliabilitas

\begin{tabular}{ll}
\hline Cronbach's Alpha & Simpulan \\
\hline 0,968 & Reliabel \\
\hline
\end{tabular}

Data yang sudah diuji dan dinyatakan valid dan reliabel untuk selanjutnya diolah menggunakan analisis regresi berganda. Tabel 4 menunjukkan hubungan antara konten, akurasi, format, kemudahan penggunaan, ketepatan waktu, kualitas informasi, kualitas sistem, kualitas layanan terhadap kepuasan pengguna.

Tabel 4. Hubungan Antara Semua Variable

\begin{tabular}{|l|c|c|}
\hline \multicolumn{1}{|c|}{ Variabel } & $\begin{array}{c}\text { Pearson } \\
\text { Correlation }\end{array}$ & $\begin{array}{c}\text { Sig. (1- } \\
\text { Tailed })\end{array}$ \\
\hline Kepuasan Pengguna & 1,000 & 0,000 \\
\hline Konten & 0,719 & 0,000 \\
\hline Akurasi & 0,729 & 0,000 \\
\hline Format & 0,747 & 0,000 \\
\hline $\begin{array}{l}\text { Kemudahan } \\
\text { Penggunaan }\end{array}$ & 0,727 & 0,000 \\
\hline Ketepatan Waktu & 0,726 & 0,000 \\
\hline Kualitas Informasi & 0,839 & 0,000 \\
\hline Kualitas Sistem & 0,859 & 0,000 \\
\hline Kualitas Layanan & 0,883 & 0,000 \\
\hline
\end{tabular}

Hasil menunjukkan bahwa nilai hubungan antara variabel konten dan kepuasan pengguna sebesar 0,719 . Nilai hubungan antara variabel akurasi dan kepuasan pengguna sebesar 0,729. Nilai hubungan antara variabel format dan kepuasan pengguna sebesar 0,747. Nilai hubungan antara variabel kemudahan penggunaan dan kepuasan pengguna sebesar 0,727. Nilai hubungan antara variabel ketepatan waktu dan kepuasan pengguna sebesar 0,726. Nilai hubungan antara variabel kualitas informasi dan kepuasan pengguna sebesar 0,839 . Nilai hubungan antara variabel kualitas sistem dan kepuasan pengguna sebesar 0,859. Nilai hubungan antara variabel kualitas layanan dan kepuasan pengguna sebesar 0,883 . Semua nilai koefisen korelasi bernilai positif yang menunjukkan bahwa hubungan antara konten, akurasi, format, kemudahan penggunaan, ketepatan waktu, kualitas informasi, kualitas sistem, kualitas layanan terhadap kepuasan pengguna searah.

Tabel 5 memberikan informasi tentang besaran statistik yang berkaitan langsung dengan hasil analisis regresi berganda. Nilai $\mathrm{R}$ square yang diahasilkan pada penelitian ini sebesar 0,820. Koefisien deteminasi ditunjukkan pada angka $\mathrm{R}$ square. Angka tersebut menunjukkan bahwa sebesar $82 \%$ kepuasan pengguna dipengaruhi oleh konten, akurasi, format, kemudahan penggunaan, ketepatan waktu, kualitas informasi, kualitas sistem dan kualitas layanan. Sedangkan sisanya, yaitu 18\% dipengaruhi oleh variabel-variabel lain di luar regresi ini.

Lebih lanjut, nilai standard error of the estimate (SEE) pada Tabel 5 adalah 1,34088. Nilai SEE digunakan untuk menilai kelayakanvariabel independen terhadap variabel dependen. Kaidah yang berlaku adalah jika nilai SEE < nilai simpangan baku maka variabel independen yang digunakan untuk memprediksi variabel dependen sudah layak. Nilai SEE pada penelitian ini sebesar 1,34088 nilai simpangan baku sebesar 3,10612. Hal ini berarti konten, akurasi, format, kemudahan penggunaan, ketepatan waktu, kualitas informasi, kualitas sistem dan kualitas layanan sudah layak dijadikan prediktor untuk variabel kepuasan pengguna. oleh karena itu konten, akurasi, format, kemudahan penggunaan, ketepatan waktu, kualitas informasi, kualitas sistem dan kualitas layanan dapat digunakan untuk menilai kepuasan mahasiswa terhadap Portal UAA. 
Tabel 5. Koefisien Determinasi Konten, Akurasi, Format, Kemudahan Penggunaan, Ketepatan Waktu, Kualitas Informasi, Kualitas Sistem dan Kualitas Layanan terhadap Kepuasan Pengguna.

\begin{tabular}{|c|c|c|c|c|}
\hline 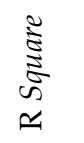 & 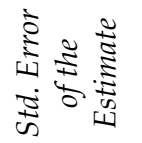 & $\underset{1}{\infty}$ & 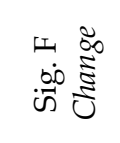 & के \\
\hline 0,820 & 1,34088 & 121.613 & 0,000 & 3,10612 \\
\hline
\end{tabular}

Tabel 6 menampilkan hasil uji ANOVA. Penelitian ini mengunakan tingkat signifikansi $a=0,05 \quad(5 \%) . \quad$ Kaidah tingkat signifikansi dikatakan baik jika nilai signifikansi (Sig.) harus lebih kecil dari 0,05. Uji anova menghasilkan nilai F sebesar 121,613 dengan tingkat signifikan sebesar 0,000. Hal ini menunjukkan bahwa konten, akurasi, format, kemudahan penggunaan, ketepatan waktu, kualitas informasi, kualitas sistem dan kualitas layanan memiliki pengaruh yang signifikan terhadap kepuasan pengguna.

Tabel 6. Uji Anova Konten, Akurasi, Format, Kemudahan Penggunaan, Ketepatan Waktu, Kualitas Informasi, Kualitas Sistem dan Kualitas Layanan Terhadap Kepuasan Pengguna.

\begin{tabular}{cc}
\hline $\mathrm{F}$ & Sig. \\
\hline 121,613 & 0,000
\end{tabular}

Tabel 7 menampilkan hasil koefisien regresi. Pada bagian ini digunakan untuk mendeskripsikan persamaan regresi untuk mengetahui angka konstan dan uji hipotesis signifikansi koefisien regresi konten, akurasi, format, kemudahan penggunaan, ketepatan waktu, kualitas informasi, kualitas sistem dan kualitas layanan memiliki pengaruh yang signifikan terhadap kepuasan pengguna Portal UAA. Persamaan regresinya adalah:

$$
\begin{gathered}
Y=a+b_{1} X_{1}+b_{2} X_{2}+b_{3} X_{3}+b_{4} X_{4}+b_{5} X_{5} \\
+b_{6} X_{6}+b_{7} X_{7}+b_{8} X_{8}
\end{gathered}
$$

Dimana:

$$
\begin{array}{ll}
\mathrm{Y} & =\text { Kepuasan Pengguna } \\
\mathrm{X}_{1} & =\text { Konten }
\end{array}
$$

$$
\begin{aligned}
& \mathrm{X}_{2} \quad=\text { Akurasi } \\
& \mathrm{X}_{3}=\text { Format } \\
& \mathrm{X}_{4} \quad=\text { Kemudahan Penggunaan } \\
& \mathrm{X}_{5} \quad=\text { Ketepatan Waktu } \\
& \mathrm{X}_{6} \quad=\text { Kualitas Informasi } \\
& \mathrm{X}_{7}=\text { Kualitas Sistem } \\
& \mathrm{X}_{8} \quad=\text { Kualitas Layanan } \\
& a=\text { angka konstan dari unstandardized } \\
& \text { coefficient yang dalam penelitian ini } \\
& \text { sebesar } 0,510 \text {. } \\
& \mathrm{b}_{1} \quad=\text { angka koefisien regresi konten } \\
& \text { sebesar } 0,033 \\
& \mathrm{~b}_{2} \quad=\text { angka koefisien regresi akurasi } \\
& \text { sebesar } 0,059 \\
& \mathrm{~b}_{3} \quad=\text { angka koefisien regresi format } \\
& \text { sebesar } 0,020 \\
& \mathrm{~b}_{4} \quad=\text { angka koefisien regresi } \\
& \text { kemudahan penggunaan sebesar } \\
& 0,092 \\
& \mathrm{~b}_{5} \quad=\text { angka koefisien regresi ketepatan } \\
& \text { waktu sebesar } 0,022 \\
& \mathrm{~b}_{6} \quad=\text { angka koefisien regresi kualitas } \\
& \text { informasi 0,074 } \\
& \mathrm{b}_{7} \quad=\text { angka koefisien regresi kualitas } \\
& \text { sistem } 0,217 \\
& \mathrm{~b}_{8} \quad=\text { angka koefisien regresi kualitas } \\
& \text { layanan } 0,377
\end{aligned}
$$

sehingga persamaan regresinya menjadi:

$$
\begin{aligned}
Y=0,510+0 & , 033 X_{1}+0,059 X_{2}+0,020 X_{3} \\
& +0,092 X_{4}+0,022 X_{5}+0,074 X_{6} \\
& +0,217 X_{7}+0,377 X_{8}
\end{aligned}
$$

Berdasarkan dengan persamaan garis regresi yang diperoleh, maka model regresi berganda tersebut menunjukkan nilai parameter model untuk konten bernilai positif $(0,033)$, yang berarti bahwa apabila nilai konten mengalami peningkatan satu poin maka kepuasan pengguna 
juga akan meningkat. Nilai parameter model untuk akurasi bernilai positif $(0,059)$, yang berarti bahwa apabila nilai akurasi mengalami peningkatan satu poin maka kepuasan pengguna juga akan meningkat. Nilai parameter model untuk format bernilai positif $(0,020)$, yang berarti bahwa apabila nilai format mengalami peningkatan satu poin maka kepuasan pengguna juga akan meningkat. Nilai parameter model untuk kemudahan penggunaan bernilai positif $(0,092)$, yang berarti bahwa apabila nilai kemudahan penggunaan mengalami peningkatan satu poin maka kepuasan pengguna juga akan meningkat. Nilai parameter model untuk ketepatan waktu bernilai positif $(0,022)$, yang berarti bahwa apabila nilai ketepatan waktu mengalami peningkatan satu poin maka kepuasan pengguna juga akan meningkat. Nilai parameter model untuk kualitas informasi bernilai positif $(0,074)$, yang berarti bahwa apabila nilai kualitas informasi mengalami peningkatan satu poin maka kepuasan pengguna juga akan meningkat. Nilai parameter model untuk kualitas sistem bernilai positif $(0,217)$, yang berarti bahwa apabila nilai kualitas sistem mengalami peningkatan satu poin maka kepuasan pengguna juga akan meningkat. Demikian juga dengan nilai parameter model untuk kualitas layanan bernilai positif $(0,377)$, yang berarti bahwa apabila nilai kualitas layanan mengalami peningkatan satu poin maka kepuasan pengguna juga akan meningkat.

Variabel yang paling berpengaruh terhadap kepuasan pengguna pada portal UAA yaitu kualitas layanan. Portal UAA dirasakan oleh pengguna mudah diakses, melakukan perbaikan dari waktu ke waktu, mendukung dan membantu layanan akademik mahasiswa, menyesuaikan kebutuhan layanan akademik, dan mahasiswa dapat mengatur portal UAA sesuai yang diinginkan. Setelah kualitas layanan, variabel yang memperngaruhi berikutnya adalah kualitas sistem, dan diikuti oleh kemudahan pengguna, kualitas informasi, akurasi, konten, ketepatan waktu dan variabel yang mempengaruhi kepuasan paling terkecil adalah format.
Tabel 7. Koefisien Regresi Konten, Akurasi, Format, Kemudahan Penggunaan, Ketepatan Waktu, Kualitas Informasi, Kualitas Sistem dan Kualitas Layanan Terhadap Kepuasan Pengguna.

\begin{tabular}{|c|c|c|c|}
\hline \multirow[t]{2}{*}{$\begin{array}{l}\overline{0} \\
\frac{0}{0} \\
\sum^{0}\end{array}$} & \multicolumn{2}{|c|}{ 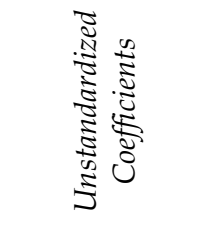 } & \multirow{2}{*}{ 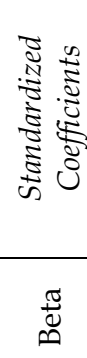 } \\
\hline & $ص$ & 离京 & \\
\hline (Constant) & 0,510 & 0,493 & \\
\hline Konten & 0,033 & 0,053 & 0,033 \\
\hline Akurasi & 0,059 & 0,084 & 0,036 \\
\hline Format & 0,020 & 0,113 & 0,011 \\
\hline $\begin{array}{l}\text { Kemudahan } \\
\text { Penggunaan }\end{array}$ & 0,092 & 0,092 & 0,049 \\
\hline Ketepatan Waktu & 0,022 & 0,091 & 0,013 \\
\hline Kualitas Informasi & 0,074 & 0,064 & 0,091 \\
\hline Kualitas Sistem & 0,217 & 0,056 & 0,271 \\
\hline Kualitas Layanan & 0,377 & 0,055 & 0,462 \\
\hline
\end{tabular}

\section{Pengujian Hipotesis}

Penelitian ini menguji delapan (8) hipotesis. Pengujian hipotesis pada penelitian ini dilakukan dengan membandingkan nilai signifikan (sig.) dengan taraf signifikansi (a) menggunakan signifikansi F. Kaidah yang digunakan yaitu hasil hipotesis akan menerima $\mathrm{H} 1$ apalabila signifikansi F hitung < alpha yang ditetapkan, dan menolak H1 apabila signifikansi F hitung > alpha yang ditetapkan [14].

\section{Pengujian Hipotesis Pertama (H1)}

H1: Konten akan memiliki pengaruh positif terhadap kepuasan pengguna pada kinerja Portal UAA.

Hasil uji signifikansi $\mathrm{F}$ menghasilkan tingkat signifikansi dengan nilai sig. $0,000<$ alpha $(\alpha=$ $0,05)$. Jadi H1 diterima, yaitu konten memiliki pengaruh positif terhadap kepuasan pada kinerja Portal UAA. Konten dapat mempengaruhi kepuasan mahasiswa dalam menggunakan portal UAA. Konten Portal UAA dirasakan dapat memberikan informasi seputar akademik yang dibutuhkan oleh mahasiswa.

\section{Pengujian Hipotesis Kedua (H2)}

H2: Akurasi akan memiliki pengaruh positif terhadap kepuasan pengguna pada kinerja Portal UAA. 
Hasil uji signifikansi $\mathrm{F}$ menghasilkan tingkat signifikansi dengan nilai sig. $0,000<$ alpha $(\alpha=$ $0,05)$. Jadi $\mathrm{H} 2$ diterima, yaitu akurasi memiliki pengaruh positif terhadap kepuasan pada kinerja Portal UAA. Akurasi dapat mempengaruhi kepuasan dalam menggunakan portal UAA. Mahasiswa merasa puas dengan keakuratan Portal UAA.

\section{Pengujian Hipotesis Ketiga (H3)}

H3: Format akan memiliki pengaruh positif terhadap kepuasan pengguna pada kinerja Portal UAA.

Hasil uji signifikansi $\mathrm{F}$ menghasilkan tingkat signifikansi dengan nilai sig. $0,000<$ alpha $(\alpha=$ $0,05)$. Jadi H3 diterima, yaitu format memiliki pengaruh positif terhadap kepuasan pada kinerja Portal UAA. Format dapat mempengaruhi kepuasan dalam menggunakan portal UAA. Mahasiswa merasakan luaran Portal UAA disajikan dalam format yang bermanfaat dan memberikan informasi akademik yang jelas.

\section{Pengujian Hipotesis Keempat (H4)}

H4: Kemudahan Penggunaan akan memiliki pengaruh positif terhadap kepuasan pengguna pada kinerja Portal UAA.

Hasil uji signifikansi $\mathrm{F}$ menghasilkan tingkat signifikansi dengan nilai sig. $0,000<$ alpha $(\alpha=$ $0,05)$. Jadi H4 diterima, yaitu kemudahan penggunaan memiliki pengaruh positif terhadap kepuasan pada kinerja Portal UAA.Portal UAA dirasakan mahasiswa mudah digunakan dan ramah pengguna.

\section{Pengujian Hipotesis Kelima (H5)}

H5: Ketepatan waktu akan memiliki pengaruh positif terhadap kepuasan pengguna pada kinerja Portal UAA.

Hasil uji signifikansi $\mathrm{F}$ menghasilkan tingkat signifikansi dengan nilai sig. $0,000<$ alpha $(\alpha=$ $0,05)$. Jadi H5 diterima, yaitu ketepatan waktu memiliki pengaruh positif terhadap kepuasan pada kinerja Portal UAA. Portal UAA memberikan informasi akademik yang terkini dan tepat waktu.

\section{Pengujian Hipotesis Keenam (H6)}

H6: Kualitas informasi akan memiliki pengaruh positif terhadap kepuasan pengguna pada kinerja Portal UAA.

Hasil uji signifikansi $\mathrm{F}$ menghasilkan tingkat signifikansi dengan nilai sig. $0,000<$ alpha $(\alpha=$ $0,05)$. Jadi H6 diterima, yaitu kualitas informasi memiliki pengaruh positif terhadap kepuasan pada kinerja Portal UAA. Portal UAA dirasakan memberikan informasi akademik yang akurat, tepat, dan mudah sesuai kebutuhan mahasiswa.

\section{Pengujian Hipotesis Ketujuh (H7)}

H7: Kualitas sistem akan memiliki pengaruh positif terhadap kepuasan pengguna pada kinerja Portal UAA.

Hasil uji signifikansi $\mathrm{F}$ menghasilkan tingkat signifikansi dengan nilai sig. $0,000<$ alpha $(\alpha=$ 0,05). Jadi H7 diterima, yaitu kualitas sistem memiliki pengaruh positif terhadap kepuasan pada kinerja Portal UAA. Portal UAA dirasakan mahasiswa sudah memenuhi persyaratan manajemen, ramah pengguna, up-to-date, dan aman.

\section{Pengujian Hipotesis Kedelapan (H8)}

H8: Kualitas layanan akan memiliki pengaruh positif terhadap kepuasan pengguna pada kinerja Portal UAA.

Hasil uji signifikansi $\mathrm{F}$ menghasilkan tingkat signifikansi dengan nilai sig. $0,000<$ alpha $(\alpha=$ $0,05)$. Jadi H8 diterima, yaitu kualitas layanan memiliki pengaruh positif terhadap kepuasan pada kinerja Portal UAA. Portal UAA dirasakan sudah melakukan perbaikan sistem dari waktu ke waktu.

\section{Kesimpulan dan Saran}

Hasil penelitian ini menunjukkan bahwa delapan (8) hipotesis diterima. Semua variabel independen memiliki pengaruh positif terhadap variabel dependen. Hasil analisis regresi berganda menghasilkan sebesar $82 \%$ kepuasan pengguna dipengaruhi oleh konten, akurasi, format, kemudahan penggunaan, ketepatan waktu, kualitas informasi, kualitas sistem dan kualitas layanan. Sedangkan sisanya, yaitu 18\% dipengaruhi oleh variabel-variabel lain di luar regresi ini. 
Hasil koefisien regresi menunjukkan bahwa variabel yang paling berpengaruh terhadap kepuasan pengguna pada portal UAA yaitu kualitas layanan. Portal UAA dirasakan oleh pengguna mudah diakses, melakukan perbaikan dari waktu ke waktu, mendukung dan membantu layanan akademik mahasiswa, menyesuaikan kebutuhan layanan akademik, dan mahasiswa dapat mengatur portal UAA sesuai yang diinginkan. Setelah kualitas layanan, variabel yang mempengaruhi berikutnya adalah kualitas sistem, dan diikuti oleh kemudahan pengguna, kualitas informasi, akurasi, konten, ketepatan waktu dan variabel yang mempengaruhi kepuasan paling terkecil adalah format. Kesimpulan dari penelitian ini dari analisis regresi berganda yang dilakukan menunjukkan bahwa mahasiswa puas terhadap kinerja Portal UAA.

Berdasarkan hasil penelitian, berikut ini beberapa saran untuk penelitian selanjutnya tentang kepuasan pengguna.

a. Para peneliti dalam bidang sejenis

Memodifikasi model evaluasi sistem informasi yang memiliki variabel yang berbeda. Penelitian ini dapat digunakan untuk mengukur kepuasan di kampus lain atau pada responden dengan angkatan yang berbeda.

\section{b. Subjek Penelitian}

Penelitian ini dapat digunakan sebagai rujukan perbaikan dan pengembangan sistem akademik (Portal UAA). Dari delapan (8) variabel yang ada, format memiliki nilai pengaruh yang paling kecil diantara yang lainnya, sehingga jika dilakukan perbaikan maka hal penting yang dapat dilakukan terlebih dahulu adalah perbaikan format dari Portal UAA. Format Portal UAA berkaitan dengan luaran sistem informasi.

\section{Referensi}

[1] Haverkort, "Information System: Introduction and Concepts," pp. 1-40, 2011.

[2] D. Kristiawan, Sunarto and M. Sabandi, "Kepuasan Pengguna Sistem Informasi Akadesmik (SIAKAD Online) di FKIP UNS dan Pengaruhnya terhadap Manfaat Peningkatan Kualitas Pembelajaran," pp. 117, 2016.
[3] W. H. DeLone and E. R. McLean, "Information Systems Success Measurement. Foundations and Trends in Information Systems," vol. 2, pp. 1-116, 2016.

[4] M. Roy and L. Bouchard, "Developing And Evaluation Methods For User Satisfaction Measurement In Practice," Journal of Information Technology Management, vol. X, pp. 49-58, 1999.

[5] S. Sirsat and M. Sirsat, "A Validation Of The Delone anda McLean On The Educational Information System Of The Maharashtra State (India)," International Journal of Education and Learning Systems, vol. 1, p. 9, 2016.

[6] L. Xiao and S. Dasgupta, "Measurement Of User Satisfaction With web-Based Information System: An Empirical Study," in Eight Americas Conferences on Information Systems, 2002.

[7] G. Antoniou and N. Papoglou, "Business Intelligence \& Analytics (BI\&A) Systems Measuring End-User Computing Satisfaction (EUCS)," Information Systems, Lund University, Swedia, 2015.

[8] A. Ilias, M. Razak, R. Rahman and M. Yasoa', "End-User Computing Satisfaction (EUCS) in Computerised Accounting System (CAS): Which the Critical Factors? A Case in Malaysia," Computer and Information Science, vol. 2, p. 18, 2009.

[9] A. Jaafreh, "Evaluation Information System Success: Applied DeLone and McLean Information System Success Model in Context Banking System in KSA," International Review of Management and Business Research, vol. 6, no. 2, pp. 829-845, 2017.

[10] S. Boell and Cecez-Kecmanovic, "What is an Information System?," in 48th Hawaii International Conferenceon System Sciences, 2015.

[11] "Analisis Penerimaan Pengguna Akhir dengan Menggunakan Technology Acceptance Model dan End User Computing Satisfaction terhadap Penerapan 
Sistem Core Banking pada BANK ABC," Semarang, 2006.

[12] M. W. Rammutloa, Application of the Delone and McLean's Model to Assess the Effectiveness of an Intranet in an Open Dintance Learning, 2017.

[13] J. Ryberg, "Mobile Technology Update to Delone and McLean Model of Information Success," 2012.

[14] R. G. Sudarmanto, Analisis Regresi Linier Ganda dengan SPSS, Yogyakarta: Graha Ilmu, 2005.
[15] N. Antoniou, G.; Papoglou, "Business Intelligence \& Analytics Measuring Enduser Satisfaction," Informatics, 2015.

[16] W. DeLone and E. R. McLean, "Information Systems Success Measurement".

[17] R. G. Sudarmanto, Analisis Regresi Linear Ganda dengan SPSS, Yogyakarta: Graha Ilmu, 2005. 